Review

\title{
Inhalation versus intravenous anaesthesia for adults undergoing on-pump or off-pump coronary artery bypass grafting: A systematic review and meta-analysis of randomized controlled trials
}

\author{
Regina El Dib ${ }^{\mathrm{a}, \mathrm{b}, \mathrm{c}, *}$, José E. Guimarães Pereira ${ }^{\mathrm{b}}$, Arnav Agarwal ${ }^{\mathrm{d}}$, Huda Gomaa ${ }^{\mathrm{e}}$, Ana Patricia Ayala ${ }^{\mathrm{f}}$, \\ Andresa Graciutti Botan ${ }^{\mathrm{a}}$, Leandro Gobbo Braz ${ }^{\mathrm{b}}$, Luciane Dias de Oliveira ${ }^{\mathrm{a}}$, \\ Luciane Cruz Lopes ${ }^{\mathrm{g}}$, Preethy J. Mathew ${ }^{\mathrm{h}}$ \\ a Institute of Science and Technology, Unesp - Univ Estadual Paulista, São Paulo, São José dos Campos, Brazil \\ b Department of Anaesthesiology, Botucatu Medical School, Unesp - Univ Estadual Paulista, São Paulo, Botucatu, Brazil \\ ${ }^{c}$ McMaster Institute of Urology, McMaster University, Hamilton, Ontario, Canada \\ d Faculty of Medicine, University of Toronto, Toronto, Canada \\ e Department of Pharmacy, Tanta Chest Hospital, Tanta, Egypt \\ ${ }^{\mathrm{f}}$ Gerstein Science Information Centre, University of Toronto, Toronto, Canada \\ ${ }^{g}$ Pharmaceutical Science Graduate Course, University of Sorocaba, São Paulo, Brazil \\ ${ }^{\mathrm{h}}$ Department of Anaesthesia and Intensive Care, Post Graduate Institute of Medical Education and Research, Chandigarh, India
}

\section{A R T I C L E I N F O}

\section{Article history:}

Received 1 April 2017

Received in revised form 3 May 2017

Accepted 20 May 2017

\section{Keywords:}

Inhalation anaesthesia

Intravenous anaesthesia

On-pump

Off-pump

Coronary artery bypass grafting

Grade

Systematic review

Randomized controlled trials

\begin{abstract}
A B S T R A C T
Study objective: To compare the use of inhalation versus intravenous anaesthesia for adults undergoing on-pump or off-pump coronary artery bypass grafting.

Design: A systematic review.

Setting: A hospital-affiliated university.

Measurements: The following databases were searched: the Cochrane Central Register of Controlled Trials (CENTRAL 2016, Issue 10), MEDLINE, EMBASE, and LILACS (from inception to October 2016). We used the GRADE approach to rate overall certainty of the evidence.

Results: In total we included 58 studies with a total of 6105 participants. The methodological quality was difficult to assess as it was poorly reported in 35 included studies (three or more domains were rated as unclear risk of bias). Two trials of sevoflurane showed a statistically significant reduction in death within 180 to 365 days of surgery (on-pump) (RR 4.10, 95\% CI 1.42 to $11.79 ; p=0.009 ; \mathrm{I}^{2}=$ not applicable; high quality of evidence). There was also a statistically significant difference favouring sevoflurane compared to propofol on both inotropic (RR $2.11,95 \% \mathrm{CI} 1.53$ to $2.90 ; p<0.00001 ; \mathrm{I}^{2}=0 \%$ ) and vasoconstrictor support needed (RR $1.51,95 \% \mathrm{CI} 1.04$ to $2.22 ; p=0.03 ; \mathrm{I}^{2}=0 \%$ ) after coronary artery bypass grafting on-pump. Two trials of sevoflurane (MD -0.22 , $95 \% \mathrm{CI}-0.41$ to $-0.03 ; p=0.02 ; \mathrm{I}^{2}=0 \%$ ) and two further trials of desflurane (MD $-0.33,95 \% \mathrm{CI}-0.45$ to $-0.20 ; p<0.00001 ; \mathrm{I}^{2}=82 \%$ ) showed a statistically significant difference on cardiac index during and after coronary artery bypass grafting on-pump, respectively.

Conclusions: There is high quality evidence that sevoflurane reduces death within 180 to 365 days of surgery and, inotropic and vasoconstrictor support compared to propofol for patients undergoing coronary artery bypass grafting. There is also some evidence showing that the cardiac index is minimally influenced by administration of sevoflurane and desflurane compared to propofol.
\end{abstract}

(c) 2017 Elsevier Inc. All rights reserved.

\section{Contents}

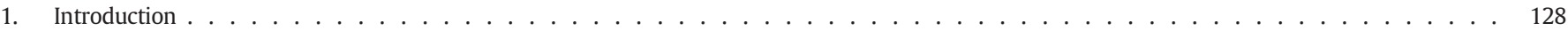

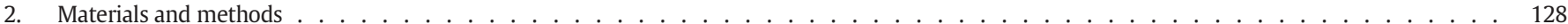

\footnotetext{
* Corresponding author at: Institute of Science and Technology, Department of Biosciences and Oral Diagnosis, Unesp - Univ Estadual Paulista, Av. Eng. Francisco José Longo, 777 - Jardim São Dimas, SP, P.O. Box 12245-000, São José dos Campos, Brazil.

E-mail addresses: eldib@fmb.unesp.br, eldib@ict.unesp.br (R. El Dib).
} 


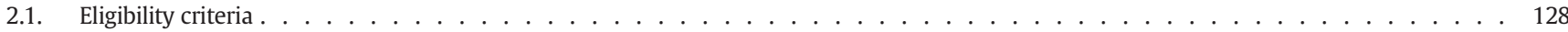

2.2. Data source and searches . . . . . . . . . . . . . . . . . . . . . . . . . . . . . . . 129

2.3. Selection of studies . . . . . . . . . . . . . . . . . . . . . . . . . . . . . . . . . . . . . 129

2.4. Data extraction and risk of bias assessment . . . . . . . . . . . . . . . . . . . . . . . . . . . . 129

2.5. Certainty of evidence . . . . . . . . . . . . . . . . . . . . . . . . . . . . 129

2.6. Data synthesis and statistical analysis . . . . . . . . . . . . . . . . . . . . . . . . . . . . . . . . 129

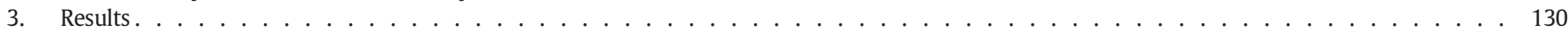

3.1. Search results . . . . . . . . . . . . . . . . . . . . . . . . . . . . . . . . . 130

3.2. Characteristics of included studies . . . . . . . . . . . . . . . . . . . . . . . . . . . . 130

3.3. Risk of bias in individual studies . . . . . . . . . . . . . . . . . . . . . . . . . . . . . . . . . . . 131

3.4. Effectiveness of interventions . . . . . . . . . . . . . . . . . . . . . . . . . . . . . . . . . . 131

3.4.1. Meta-analysis comparing sevoflurane versus propofol . . . . . . . . . . . . . . . . . . . . . 131

3.4.2. Meta-analysis comparing isoflurane versus propofol . . . . . . . . . . . . . . . . . . . . . . . . . . . . . . . . . . . 132

3.4.3. Meta-analysis comparing desflurane versus propofol. . . . . . . . . . . . . . . . . . . . . . . . . . 132

3.4.4. Meta-analysis comparing enflurane versus propofol . . . . . . . . . . . . . . . . . . . . . . . . . . . 132

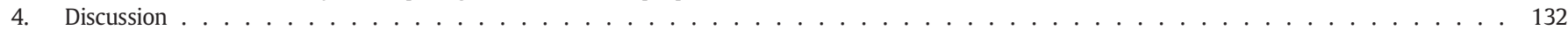

4.1. Summary of main results . . . . . . . . . . . . . . . . . . . . . . . . . . . . . . . . . 132

4.2. Overall completeness and applicability of evidence. . . . . . . . . . . . . . . . . . . . . . . . . . . 133

4.3. Quality of the evidence . . . . . . . . . . . . . . . . . . . . . . . . . . . . 135

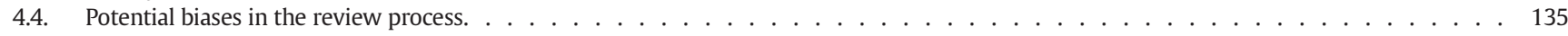

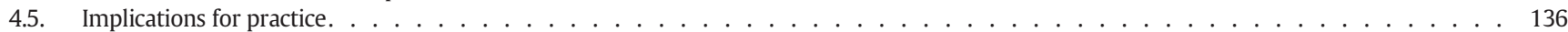

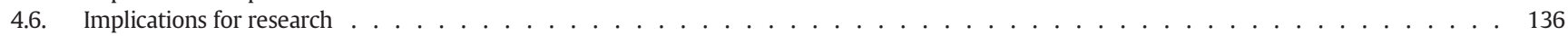

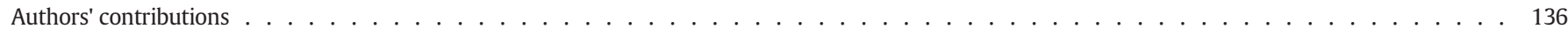

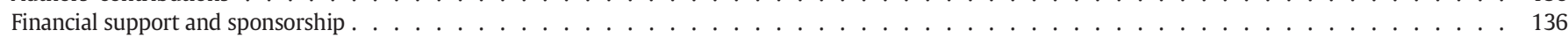

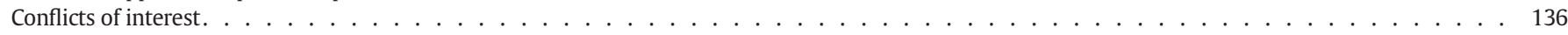

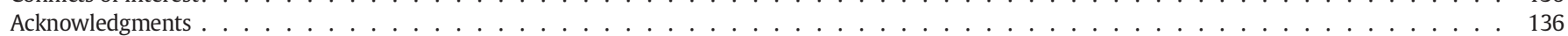

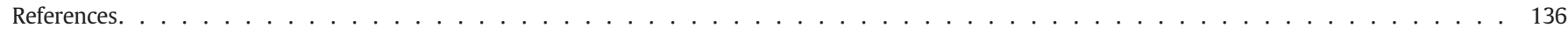

\section{Introduction}

Inhalation anaesthetics such as isoflurane, desflurane and sevoflurane have been shown to depress myocardial contractility in animal and human studies [1], and their haemodynamic effects have been observed in humans with or without heart disease [2]. There is also evidence to suggest that inhalational anaesthetics may have cardioprotective properties [3]. Two reviews of the MEDLINE and Science Citation Index databases, respectively, reported that sevoflurane and desflurane reduce biomarker of cardiac injury in the postoperative period and that sevoflurane improves long-term outcomes [4,5]. Furthermore, a systematic review comparing inhalational with intravenous anaesthesia for coronary artery bypass grafting surgery found that the use of volatile agents was associated with lower serum troponin I concentrations (indicating a potential reduction in cardiac injury) and also a reduced length of hospital stay [6].

Several experimental studies using a variety of protocols have shown that anaesthetic agents protect against ischemia and reperfusion injury [7-10]. Several groups have reported that inhalational anaesthetics confer organ protection through this mechanism, and it has been proposed that there are similarities between pharmacological preconditioning afforded by halogenated anaesthetics and ischemic preconditioning [11].

The outcome of this review is expected to yield information to help clinicians decide the anaesthetic plan that may benefit public health at large. As the extent of cardioprotection is influenced by the choice of anaesthetic agent, identifying the best approach for patients undergoing on-pump or off-pump coronary artery bypass grafting reduces complications and costs. Therefore, we verified the efficacy and safety of intravenous versus inhalation anaesthesia in decreasing mortality and morbidity for adults undergoing on-pump or off-pump coronary artery bypass grafting.

\section{Materials and methods}

The Cochrane Handbook for Intervention Reviews [12] guided our choice of methods. This systematic review of the literature on interventional studies was conducted in accordance with the PRISMA (Preferred Reposting Items for Systematic Reviews and Meta-analysis) statement [13].

\subsection{Eligibility criteria}

We considered all RCTs evaluating inhalation anaesthesia (e.g. sevoflurane, isoflurane, desflurane, enflurane) compared to intravenous anaesthesia (e.g. propofol, fentanyl) in adults (aged 18 years old and above) undergoing on-pump or off-pump coronary artery bypass grafting, regardless of gender. We excluded participants having valve surgery and those who had central neuraxial blockade.

Eligible studies reported one or more of the following: a) death within 24 h of surgery; b) death within 30 days of surgery; c) death within 180 to 365 days of surgery; d) renal insufficiency from the date of randomization, measured by neutrophil gelatinase-associated lipocalin (NGAL), 'Risk, Injury, Failure, Loss, End-stage' kidney disease (RIFLE), creatinine, cistatin or other; e) cardiac depression measured by haemodynamic variables and/or by vasoactive drugs (e.g., noradrenaline) or inotropic (e.g., dopamine, adrenaline); f) intraoperative awareness (as subsequently reported by the participant); $g$ ) length of stay in both hospital and intensive care unit and; $h$ ) adverse postoperative outcomes such as:

- pneumonia, defined as an acute or chronic disease marked by inflammation of the lungs determined by clinical examination or $\mathrm{x}$-ray, or both;

- stroke, defined as a sudden loss of brain function measured by magnetic resonance imaging (MRI) or computed tomography (CT);

- acute renal failure, defined as the inability of the kidneys to excrete waste measured by the RIFLE classification [14] or Acute kidney injury Network (AKIN) criteria [15] or other biomarkers such as NGAL, interleukin 18 and kidney injury molecule-1;

- arrhythmia, defined as any abnormality in the rhythm of the heart measured by electrocardiogram or echocardiography;

- nausea and vomiting measured by frequency and severity;

- pain measured by any validated tool such as the visual analogue scale (VAS);

- brain injury measured by the cerebral performance category (CPC) or other equivalent validated scales;

- heart failure, defined as the inability of the heart to pump blood, measured by clinical signs, X-ray, electrocardiogram or echocardiography;

- myocardial infarction, defined as sudden chest pain, shortness of breath, 
nausea and anxiety, determined by electrocardiogram, echocardiography, and various blood markers such as creatine kinase-MB and troponin;

- blood transfusion, defined as the need to receive blood products and determined by volume administered by body weight.

Systematic reviews of eligible RCTs were included for the identification of eligible studies through a review of reference lists. Animal studies, case reports and narrative review articles were excluded.

\subsection{Data source and searches}

The search was performed in the following electronic databases: the Cochrane Central Register of Controlled Trials (CENTRAL Issue 10 2016), MEDLINE (OvidSP, 1966 to October 2016), Embase (OvidSP, 1980 to October 2016), LILACS (BIREME interface, 1982 to October 2016), and ongoing trials databases such as http://www.controlled-trials.com/and http:// clinicaltrials.gov. The databases were searched for available published and unpublished studies from inception through to October 27, 2016.

The search was conducted using multiple combinations of the following key words: "Myocardial Revascularization", "Inhalation Anaesthesia", and "Intravenous Anaesthesia" (Table 1). No restrictions were placed on language, year of publication or publication status.

In addition, a manual search of the reference lists of potential primary studies was conducted, and several major anesthesiology journals were hand-searched for additional eligible studies.

\subsection{Selection of studies}

Using pre-standardized screening forms and protocols, teams of two reviewers independently screened all titles and abstracts identified by the literature search, obtained full-text articles of all potentially eligible studies, and evaluated these studies for eligibility. Reviewers resolved disagreement through discussion, with third party adjudication if necessary.

\subsection{Data extraction and risk of bias assessment}

Three pairs of reviewers independently extracted the following data using a pre-standardized data extraction form: characteristics of the study design; participants; interventions; outcomes event rates and follow-up. Authors of eligible studies were contacted by reviewers to identify missing data and confirm data accuracy of eligible studies.

Reviewers independently assessed risk of bias by using the risk of bias approach for Cochrane reviews [16]. We used the following five separate criteria: adequacy of sequence generation, allocation sequence concealment, blinding, incomplete outcome data, selective outcome reporting. For incomplete outcome data, we considered loss to followup of $<10 \%$ and a difference of $<5 \%$ in missing data between intervention and control groups as low risk of bias.

\subsection{Certainty of evidence}

The reviewers used the Grading of Recommendations Assessment, Development and Evaluation (GRADE) methodology to rate certainty of evidence for each outcome as high, moderate, low, or very low [17]. Detailed GRADE guidance was used to assess overall risk of bias [18], imprecision [19], inconsistency [20], indirectness [21] and publication bias [22], and results were summarized in an evidence profile.

\subsection{Data synthesis and statistical analysis}

We calculated pooled risk ratios (RRs) for dichotomous outcomes and mean difference (MD) for continuous variables, with both the associated 95\% CIs using random-effects models with the Mantel-Haenszel statistical method. We addressed variability in results across studies
Table 1

Search strategy.

1 CENTRAL search strategy

\#1 MeSH descriptor: [Myocardial Revascularization] explode all trees \#2 (myocard* near revascular*) or Internal Mammary Artery Implantation \#3 \#1 or \#2

\#4 MeSH descriptor: [Anesthesia, Inhalation] explode all trees \#5 MeSH descriptor: [Anesthesia, Intravenous] explode all trees \#6 MeSH descriptor: [Isoflurane] explode all trees \#7 MeSH descriptor: [Propofol] explode all trees \#8 MeSH descriptor: [Hydrocarbons, Fluorinated] explode all trees \#9 MeSH descriptor: [Halothane] explode all trees

\#10 isoflurane or sevoflurane or sevorane or halothane or ftorotan* or narcotan or ultane or 1,1,1-trifluoro-2-chloro-2-bromoethane or fluothan* or enfluran* or etran or ethrane or enlirane or enfran or propofol* or 2,6?diisopropylphenol or disoprofol or diprivan or ici?35?868 or recofol or aquafol

\#11 (an?esth* near (insufflation or inhalation or intravenous)):ti,ab $\# 12$ \#4 or \#5 or \#6 or \#7 or \#8 or \#9 or \#10 or \#11 \#13 \#3 and \#12

\section{Search strategy for MEDLINE (OvidSP)}

1 exp. Myocardial Revascularization/ or (myocard* adj4 revascular*).af. or Internal Mammary Artery Implantation.mp.

2 exp. Anesthesia, Inhalation/ or exp. Anesthesia, Intravenous/ or exp. Isoflurane/ or exp. Propofol/ or Hydrocarbons, Fluorinated/ or Halothane/ or (isoflurane or sevoflurane or sevorane or halothane or ftorotan* or narcotan or ultane or 1,1,1-trifluoro-2-chloro-2-bromoethane or fluothan* or enfluran* or etran or ethrane or enlirane or enfran or propofol* or 2,6?diisopropylphenol or disoprofol or diprivan or ici?35?868 or recofol or aquafol).mp. or (an?esth* adj3 (insufflation or inhalation or intravenous)).ti,ab.

31 and 2

4 ((randomized controlled trial or controlled clinical trial).pt. or randomized.ab. or placebo.ab. or drug therapy.fs. or randomly.ab. or trial.ab. or groups.ab.) not (animals not (humans and animals)).sh.

53 and 4

\section{Embase (Ovid SP) search strategy}

1. exp. heart muscle revascularization/ or (myocard* adj4 revascular*).af. or Internal Mammary Artery Implantation.mp.

2. exp. inhalation anesthesia/ or exp. intravenous anesthesia/ or exp. isoflurane/ or exp. propofol/ or exp. fluorinated hydrocarbon/ or exp. halothane/ or (isoflurane or sevoflurane or sevorane or halothane or ftorotan* or narcotan or ultane or 1,1,1-trifluoro-2-chloro-2-bromoethane or fluothan* or enfluran* or etran or ethrane or enlirane or enfran or propofol* or 2,6?diisopropylphenol or disoprofol or diprivan or ici?35?868 or recofol or aquafol).mp. or (an?esth* adj3 (insufflation or inhalation or intravenous)).mp.

3. 1 and 2

4. (randomized-controlled-trial/ or randomization/or controlled-study/or multicenter-study/ or phase-3-clinical-trial/ or phase-4-clinical-trial/ or double-blind-procedure/ or single-blind-procedure/ or (random* or cross?over* or multicenter* or factorial* or placebo* or volunteer*).mp. or ((singl* or doubl* or trebl* or tripl*) adj3 (blind* or mask*)).ti,ab. or (latin adj square).mp.) not (animals not (humans and animals)) sh.5.3 and 4

\begin{tabular}{l}
\hline L LILACS (BIREME) search strategy \\
\hline ((myocard\$ and revascular\$) or (Internal Mammary Artery Implantation)) and \\
(isoflurane or sevoflurane or sevorane or halothane or ftorotan\$ or narcotan or \\
ultane or 1,1,1-trifluoro-2-chloro-2-bromoethane or fluothan\$ or enfluran\$ or \\
etran or ethrane or enlirane or enfran or propofol\$ or 2,6-diisopropylphenol or \\
disoprofol or diprivan or ici-35?868 or recofol or aquafol or (an?esth\$ and \\
(insufflation or inhalation or intravenous))) \\
\hline
\end{tabular}

by using $\mathrm{I}^{2}$ statistic and the $P$ value obtained from the Cochran chi square test. Our primary analyses were based on eligible patients who had reported outcomes for each study (complete case analysis).

To perform the meta-analysis we considered the last follow-up of each following variable: during coronary artery bypass grafting, and after-coronary artery bypass grafting. For example, if a study reported haemodynamic data on the beginning of ischaemia and at $15 \mathrm{~min}$ after ischaemia, we chose the latter period to plot studies on the variable during-coronary artery bypass grafting. Furthermore, studies that mentioned a variable as during cardiopulmonary bypass and did not specify if it was during coronary artery bypass grafting, were also considered as during coronary artery bypass grafting. 
We performed subgroup analyses according to the different methods: different type of inhalation anaesthetics (e.g. isoflurane, sevoflurane, desflurane); different type of intravenous anaesthetics (e.g. propofol); different haemodynamic variables to measure cardiac depression; different echocardiographic parameters to measure myocardial infarction; lenght of stay (hospital versus intensive care unit); on-pump versus off-pump; inotropic versus vasoconstrictive support nedded; and perioperative versus postoperative period.

We planned to perform separate analyses for comorbidities (diabetes, hypertension, endocrinopathies, etc.) and age ( $\geq 18$ to 60 years old versus $>60$ years old; and we also planned to assess publication bias through visual inspection of funnel plots for outcomes addressed in 10 or more studies; however, the information from the included studies was insufficient for performance of any of these analyses. We used Review Manager (RevMan) (version 5.3; Nordic Cochrane Centre, Cochrane) for all analyses [23].

\section{Results}

\subsection{Search results}

We identified a total of 1407 (after removing duplicates) citations from the database searches. After screening by title, and then by abstract, we obtained full-text copies for 75 citations that were potentially eligible for inclusion in the review. Of those 17 did not fulfil our eligibility criteria and were excluded. We therefore included 58 studies [9,24-26,27-80] with a total of 6105 randomized and 6073 analysed participants in this review. No additional eligible studies were identified based on handsearching of major anaesthesia journals or manual review of reference lists of relevant primary studies and systematic reviews (Fig. 1).

\subsection{Characteristics of included studies}

All of the 58 included studies were reported as RCTs. Sample sizes ranged from 18 [55], to 868 [56] participants.

The trials took place in a variety of settings:

- Eight trials took place in North America $[30,38,40,42,43,46,60,62]$.

- Thirty-two trials in Europe [9,24-26,28,29,32-34,36,37,39,41,45,50, 52-57,59,61,64-66,68,69,70,72,74,78].

- Three trials in Turkey (Euro-Asian country) $[27,35,48]$.

- Three trials in Australia [63,67,75].

- One trial in South America [79].

- One trial in Japan [49], one in Korea [51]; three in India [73,76,77]; two in Taiwan [31,58]; and one trial in China [47].

- Three trials did not specify where the study was conducted $[44,71,80]$.

All except ten of the trials included both male and female participants. Of those ten trials, seven did not report the gender of the participants $[25,36,49,64,65,68,70]$. The remaining three trials $[47,48,59]$ included only male patients.

All trials included adults only. Sixteen trials included participants under 60 years of age $[27,35,41,42,44,50,52,55,65,68,70,73,74,77-79]$. Five trials did not report the age of the participants $[27,28,49,61,64]$. Of the remaining trials, the mean age of the participants in each group trials ranged from 48.9 years to 76 years, with an average mean age for the groups of 63.7 years (range 50.0 to 75.0 years) (Table 2).

All trials reporting follow-up durations followed up the participants beyond the end of the treatment period. The duration of post-treatment follow-up ranged from 15 min post-surgery [45], to a follow-up duration of one year in four studies $[34,39,54,56]$. Fifteen trials did not report treatment and follow-up duration [25,27,28,31,36,37,48,49,51,55,60,63, $64,67,75,79]$.

Various anaesthetics agents were used in the different trials. 44 studies used propofol [9,24-26,27-33,35,37-39,41,42,44,45,47-57,59,60,63, $64,67,69,71,72,74,75-78,80]$; sevoflurane in 25 studies [9,24,28,29,32,

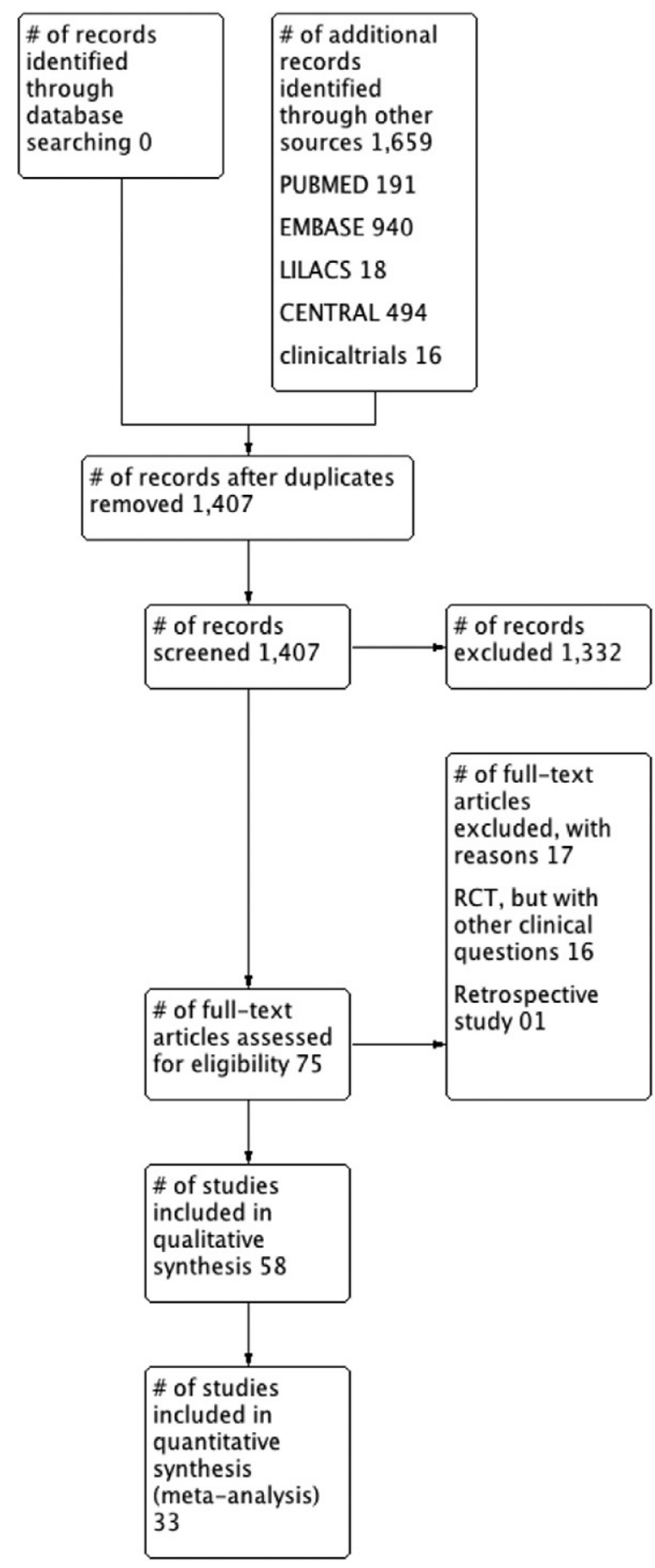

Fig. 1. PRISMA diagram of included studies.

33-35,37,40,45,47,49,51,54-57,59,64,67,72,73,75,76]; desflurane in nine trials [25-27,33,34,43,68,71,76]; isoflurane 23 trials [31,35,36,38, $39,41,44,48,50,52,53,58,64,65,67,69,70,73-75,77,79,80]$; enflurane in seven studies [30,42,60,62,63,70,78]; halothane in two trials [70,79]; sufentanil in three trials $[37,43,62]$; TIVA in six studies $[26,34,40,56,73$, 76]; midazolam in six trials [36,37,44,52,62,70]; and, in one trial each, thiopental [60]; flunitrazepam [41]; and thiopentone and diazepam and fentanyl and droperidol and pancuronium [65].

Fifteen trials reported the primary outcomes of death $[24,26,34,38$, $39,42,44,54,56,57,60,65,71,75,79]$.

Renal insufficiency was reported in only two trials [75,79]. Cardiac depression was reported in 29 studies [9,24,26,29,31-33,35,38,40-42, $44,45,50,52,54,56,57,59,60,62,63,68-71,74,79]$. Eleven trials reported 
Table 2

GRADE evidence profile for RCTs: Sevoflurane versus propofol in critical care units and university hospitals in Europe, a university in Chile, and a tertiary referral hospital in Australia.

\begin{tabular}{|c|c|c|c|c|c|c|}
\hline \multirow[t]{2}{*}{ Outcomes } & \multicolumn{2}{|c|}{$\begin{array}{l}\text { Illustrative comparative } \\
\text { risks* }(95 \% \mathrm{CI})\end{array}$} & \multirow[t]{2}{*}{$\begin{array}{l}\text { Relative effect } \\
(95 \% \mathrm{CI})\end{array}$} & \multirow{2}{*}{$\begin{array}{l}\text { No of } \\
\text { participants } \\
\text { (studies) }\end{array}$} & \multirow{2}{*}{$\begin{array}{l}\text { Quality of } \\
\text { the evidence } \\
\text { (GRADE) }\end{array}$} & \multirow[t]{2}{*}{ Comments } \\
\hline & $\begin{array}{l}\text { Risk with } \\
\text { sevoflurane }\end{array}$ & Risk with propofol & & & & \\
\hline Death within $24 \mathrm{~h}$ of surgery & NR & NR & NR & NR & NR & $\begin{array}{l}\text { No included studies reported } \\
\text { on this outcome. }\end{array}$ \\
\hline $\begin{array}{l}\text { Death within } 30 \text { days of surgery (on-pump and } \\
\text { off-pump) }\end{array}$ & 8 per 1000 & $\begin{array}{l}8 \text { more per } 1000 \\
\text { ( } 7 \text { fewer to } 118 \\
\text { more) }\end{array}$ & $1.00(0.06,15.80)$ & 556 (2 studies) & $\begin{array}{l}\oplus \oplus \Theta \Theta \\
\text { low }^{\mathrm{a}-\mathrm{d}}\end{array}$ & $\begin{array}{l}\text { Baseline risk estimates come } \\
\text { from control arm of the Story } \\
2001 \text { study. }\end{array}$ \\
\hline Death within 180 to 365 days of surgery (on-pump) & 30 per 1000 & $\begin{array}{l}93 \text { more per } 1000 \\
\text { (13 more to } 324 \\
\text { more) }\end{array}$ & $4.10(1.42,11.79)$ & 597 (2 studies) & $\begin{array}{l}\oplus \oplus \oplus \oplus \\
\text { high }^{\mathrm{d}-\mathrm{f}}\end{array}$ & $\begin{array}{l}\text { Baseline risk estimates come } \\
\text { from control arm of the De } \\
\text { Hert } 2009 \text { study. }\end{array}$ \\
\hline $\begin{array}{l}\text { Renal insufficiency (haemofiltration for those with } \\
\text { creatinine increases }>44 \mu \mathrm{m} \text { ) (on-pump) } \\
\text { follow-up: not reported }\end{array}$ & 100 per 1000 & $\begin{array}{l}23 \text { fewer per } 1000 \\
\text { (92 fewer to } 665 \\
\text { more) }\end{array}$ & $0.77(0.08,7.65)$ & 63 (2 studies) & $\begin{array}{l}\oplus \oplus \Theta \Theta \\
\operatorname{low}^{\mathrm{a}, \mathrm{c}, \mathrm{d}, \mathrm{g}}\end{array}$ & $\begin{array}{l}\text { Baseline risk estimates come } \\
\text { from control arm of the Story } \\
2001 \text { study. }\end{array}$ \\
\hline $\begin{array}{l}\text { Length of stay in the intensive care unit (on-pump) } \\
\text { follow-up: } 12 \mathrm{~h} \text { after the arrival in the intensive } \\
\text { care unit }\end{array}$ & & & $\begin{array}{l}\text { MD } 1080.00 \\
(612.10,1547.90)\end{array}$ & 320 (1 study) & $\begin{array}{l}\oplus \oplus \oplus \oplus \\
\text { high }^{\mathrm{d}-\mathrm{f}}\end{array}$ & \\
\hline $\begin{array}{l}\text { Adverse postoperative outcome - myocardial } \\
\text { infarction (on-pump) } \\
\text { follow-up: } 12 \text { h after the arrival in the intensive } \\
\text { care unit (Lorsomradee 2006) and, one year (De } \\
\text { Hert 2009) }\end{array}$ & 23 per 1000 & $\begin{array}{l}24 \text { more ( } 5 \text { fewer to } \\
100 \text { more) }\end{array}$ & $2.04(0.78,5.33)$ & 597 (2 studies) & $\begin{array}{l}\oplus \oplus \oplus \ominus \\
\text { moderate }^{\mathrm{c}-\mathrm{e}}\end{array}$ & $\begin{array}{l}\text { Baseline risk estimates come } \\
\text { from control arm of the De } \\
\text { Hert } 2009 \text { study. }\end{array}$ \\
\hline
\end{tabular}

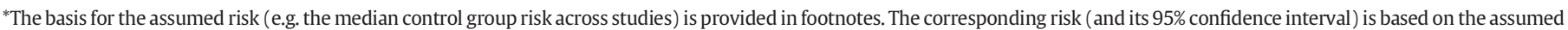
risk in the comparison group and the relative effect of the intervention (and its 95\% CI). CI: Confidence interval; RR: Risk Ratio; NR: Not reported.

GRADE Working Group grades of evidence

High quality: Further research is very unlikely to change our confidence in the estimate of effect.

Moderate quality: Further research is likely to have an important impact on our confidence in the estimate of effect and may change the estimate.

Low quality: Further research is very likely to have an important impact on our confidence in the estimate of effect and is likely to change the estimate.

Very low quality: We are very uncertain about the estimate.

a There was no serious limitation related to inconsistency (not applicable), and indirectness.

b There was serious limitation related to risk of bias (allocation concealment in the Orriach 2013 study).

c There was serious limitation related to imprecision as 95\% CI for absolute effects include clinically important benefit and no benefit.

d Publication bias was undetectable.

e There was no serious limitation related to risk of bias, inconsistency (not applicable), and indirectness.

f There was no serious limitation related to imprecision as $95 \% \mathrm{CI}$ for absolute effects include only clinically important benefit favouring the use of sevoflurane.

g There was serious limitation related to risk of bias (allocation concealment in the Urzua 1996 study).

on either length of hospital or intensive care unit stay $[31,44,47,51,54$, 56-58,60,63,79].

Nineteen trials reported on adverse postoperative outcomes [24,26, $29,32-34,38,39,69,42,50,51,57,59,60,62,63,71,79]$. Only four trials [30, $42,68,79]$ reported on intraoperative awareness.

\subsection{Risk of bias in individual studies}

Fig. 2 describes the risk of bias assessment for the RCTs. The overall methodological quality of the included studies was about evenly split between those in which the classification was unclear and those in which the studies were categorised as low risk of bias. Allocation concealment was a major risk of bias limitation in three trials $[28,45,66]$ and blinding of participants and personnel and outcome assessors in eight $[30,35,36,37,53,61,63,70]$.

\subsection{Effectiveness of interventions}

\subsubsection{Meta-analysis comparing sevoflurane versus propofol}

3.4.1.1. Death within 180 to 365 days of surgery. Results from two RCTs [34,57] suggested a statistically significantly reduction with the use of sevoflurane compared to propofol in death within 180 to 365 days of surgery during on-pump (RR 4.10, 95\% CI 1.42 to $11.79 ; p=0.009 ; \mathrm{I}^{2}$ $=$ not applicable; participants $=597$ ) (Fig. 3 ). The quality of evidence was rated high for this outcome (Table 2).

3.4.1.2. Cardiac depression measured by haemodynamic variables. Based on 82 participants reported from two RCTs $[29,45]$ there was a statistically significant difference favouring the use of sevoflurane compared to propofol on cardiac index $\left(\mathrm{L} / \mathrm{min}^{-1}\right)(\mathrm{MD}-0.22,95 \% \mathrm{CI}-0.41$ to
$-0.03 ; p=0.02 ; \mathrm{I}^{2}=0 \%$; participants $=82$ ) during coronary artery bypass grafting off-pump (Fig. 4). However, there was no statistically significant difference between sevoflurane and propofol on central venous pressure $(\mathrm{mmHg})\left(\mathrm{MD} 0.76,95 \% \mathrm{CI}-0.04\right.$ to $1.55 ; p=0.06 ; \mathrm{I}^{2}=$ $0 \%$; participants $=82$ ) neither on mean arterial pressure $(\mathrm{mmHg})$ (MD $1.71,95 \% \mathrm{CI}-1.03$ to $4.44 ; p=0.22 ; \mathrm{I}^{2}=0 \%$; participants $=$ 82) (Fig. 4).

3.4.1.3. Cardiac depression measured by vasoactive drugs. Based on 350 participants reported from two RCTs [40,57], there was a statistically significant difference favouring sevoflurane compared to propofol on both inotropic support needed (RR 2.11,95\% CI 1.53 to 2.90; $p<$ $0.00001 ; \mathrm{I}^{2}=0 \%$; participants $\left.=350\right)$ and vasoconstrictor support needed (RR $1.51,95 \%$ CI 1.04 to $2.22 ; p=0.03$; $I^{2}=0 \%$; participants $=350$ ) after coronary artery bypass grafting on-pump (Fig. 5).

3.4.1.4. Adverse postoperative outcome - myocardial infarction measured by echocardiographic parameters. Myocardial infarction measured by echocardiographic parameters after coronary artery bypass on-pump was reported in two trials (442 participants) [32,33]. Based on 50 participants, there was a statistically significant difference favouring sevoflurane compared to propofol on peak left ventricular pressure (mmHg) (MD - 7.47, 95\% CI - 11.67 to $-3.27 ; p=0.0005 ; \mathrm{I}^{2}=0 \%$; participants $=50$ ) (Fig. 6).

3.4.1.5. Length of stay in intensive care unit. One study reported on length of stay in intensive care unit on the subgroup off-pump [51]. Based on 94 participants, there was no statistically significant difference between sevoflurane and propofol (MD 22.00, 95\% CI - 581.27 to 625.27; $p=$ $0.94 ; \mathrm{I}^{2}=0 \%$; participants $=94$ ) (Appendix Fig. 1 ). Based on 320 participants, the pooled result for length of stay demonstrated that there was 


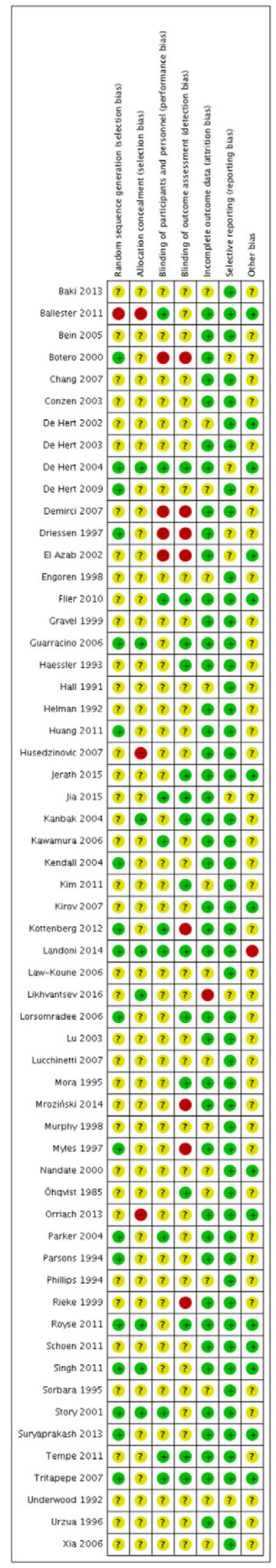

Fig. 2. Risk of bias in individual studies. evidence of a reduction in length of stay in intensive care unit with the use of sevoflurane when compared to propofol (MD 1080.00,95\% CI 612.10 to 1547.90; $p<0.00001 ; I^{2}=0 \%$; participants = 320) (Appendix Fig. 1).

\subsubsection{Meta-analysis comparing isoflurane versus propofol}

Death within 180-365 days was studied in four trials (450 participants) $[38,39,44,75]$, and all participants were within the on-pump subgroup. There were three events of death in the propofol group, and no events in the isoflurane group. The pooled result for death within 180-365 days, using the random-effect model, demonstrated that there was no evidence of a reduction in death with the use of either isoflurane or propofol ( $\mathrm{RR} 3.84,95 \% \mathrm{CI} 0.43$ to $34.22 ; p=0.23 ; \mathrm{I}^{2}=$ $0 \%$; participants $=450$ ) (Fig. 7). The quality of evidence was moderate for this outcome. We downgraded the quality of evidence from high to moderate because of serious imprecision (Table 3 ).

\subsubsection{Meta-analysis comparing desflurane versus propofol}

Two studies reported on cardiac index $\left(\mathrm{L} / \mathrm{min}^{-1}\right)[33,71]$. Based on 208 participants, there was a significant difference favouring desflurane compared to propofol ( $\mathrm{MD}-0.33,95 \% \mathrm{CI}-0.45$ to $-0.20 ; p<0.00001$; $\mathrm{I}^{2}=82 \%$; participants $=208$ ) after coronary artery bypass grafting onpump (Fig. 8). However, there was no statistically significant difference between desflurane and propofol related to mean pulmonary artery pressure (mm Hg) (MD 0.00, 95\% CI -1.32 to $1.32 ; p=1.00 ; \mathrm{I}^{2}=$ $0 \%$; participants $=208$ ) (Fig. 8). The overall meta-analysis showed also a significant difference favouring desflurane compared to propofol ( $\mathrm{MD}-0.32,95 \% \mathrm{CI}-0.45$ to $-0.20 ; p<0.00001 ; \mathrm{I}^{2}=49 \%$; participants = 208) (Fig. 8) (Table 4).

\subsubsection{Meta-analysis comparing enflurane versus propofol}

Death within 30 days of surgery was reported in two trials $[42,60]$. There were no deaths in the propofol group, and one event in the enflurane group. The pooled result for this outcome demonstrated that there was no evidence of a reduction in death within 30 days with the use of either enflurane or propofol (RR $0.35,95 \% \mathrm{CI} 0.01$ to 8.11; participants $=94 ; p=0.51 ; I^{2}=0 \% ; 94$ participants) (Appendix Fig. 2).

The included studies do not address all of the objectives of the review because many of them did not report data in a usable way or did not measure the primary outcomes. For the other variables studied such as renal insufficiency, adverse postoperative outcome (e.g. stroke) and biochemical biomarkers of myocardial damage (e.g., troponin) we believe that there was no statistically significance difference regarding inhalation and intravenous anaesthetics.

\section{Discussion}

\subsection{Summary of main results}

To the best of our knowledge, this is the first systematic review to synthesise all available data from randomized controlled trials relating to the efficacy of inhalation versus intravenous anaesthesia for adults undergoing on-pump or off-pump coronary artery bypass grafting. The results of the review suggest that sevoflurane shows promise in coronary artery bypass grafting. We set out to identify the best clinical evidence available to answer our question, and performed an extensive search with careful quality assessment, and therefore we found some conclusions from the trials that were included.

The methodological descriptions reported inadequate methods of randomization and allocation concealment, and there were limitations to the blinding. Further, the majority of the included trials did not address the same outcomes and for this reason the pooling of data was seldom possible. The small number of trials, and the sometimes low methodological quality, meant that our intended sensitivity analyses were not possible.

The main findings of this review is that, although we had included a reasonable number of included studies ( 58 trials) that evaluated the 


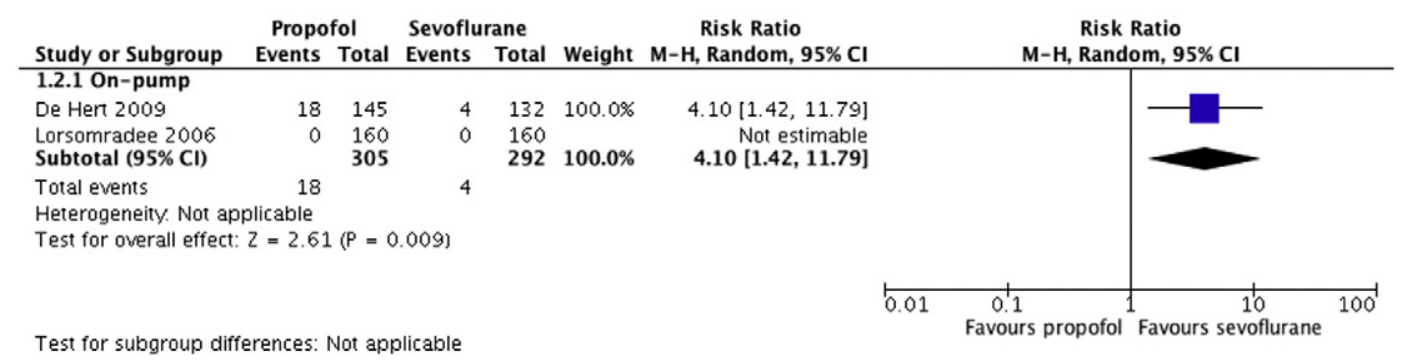

Fig. 3. Meta-analysis of death within 180 to 365 days of surgery comparing sevoflurane versus propofol.

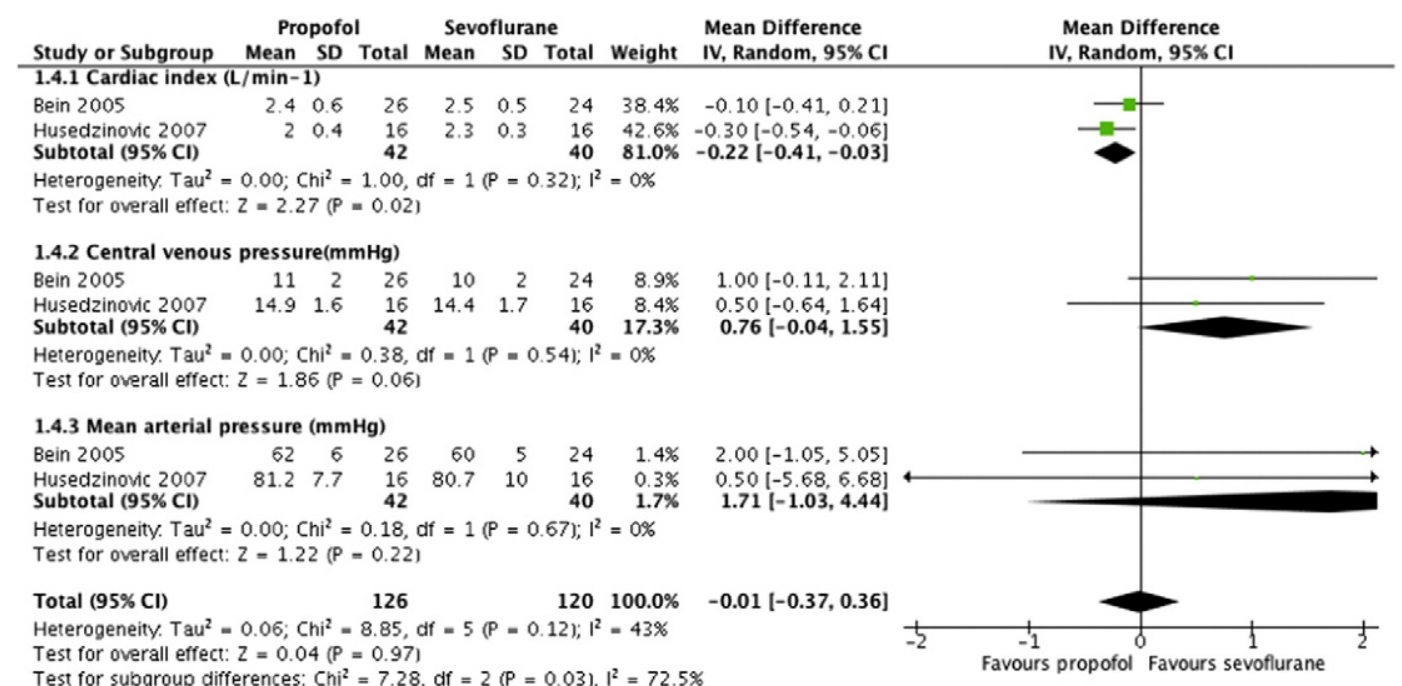

Fig. 4. Meta-analysis of cardiac depression measured by haemodynamic variables during coronary artery bypass grafting off-pump comparing sevoflurane versus propofol.

effect of inhalation versus intravenous anaesthesia in decreasing mortality and morbidity for patients undergoing on-pump or off-pump coronary artery bypass grafting, we found some evidence suggesting the use of sevoflurane compared to propofol in the reduction of death within 180 to 365 days and inotropic and vasoconstrictor support. Also, there was some evidence showing that the cardiac index is minimally influenced by administration of sevoflurane and desflurane compared to propofol.

Inhalation anaesthetics present a lower cost compared to intravenous aesthetics and very few risks that can be recommend to the clinical practice. A study [38] evaluated the drug costs of sevoflurane and propofol in which the former one showed less than twice the price of propofol with a mean cost of US\$ 58.08 versus US\$129.91, respectively.

\subsection{Overall completeness and applicability of evidence}

The main limitation of our findings is that although we have included 58 studies, the heterogeneity related to the clinical outcomes was high to allow that all included studies was plotted into the same meta-analysis; also some of the included studies poorly described the outcomes of interest, and therefore the evidence was insufficient to allow firm conclusions to be drawn for many of our outcome

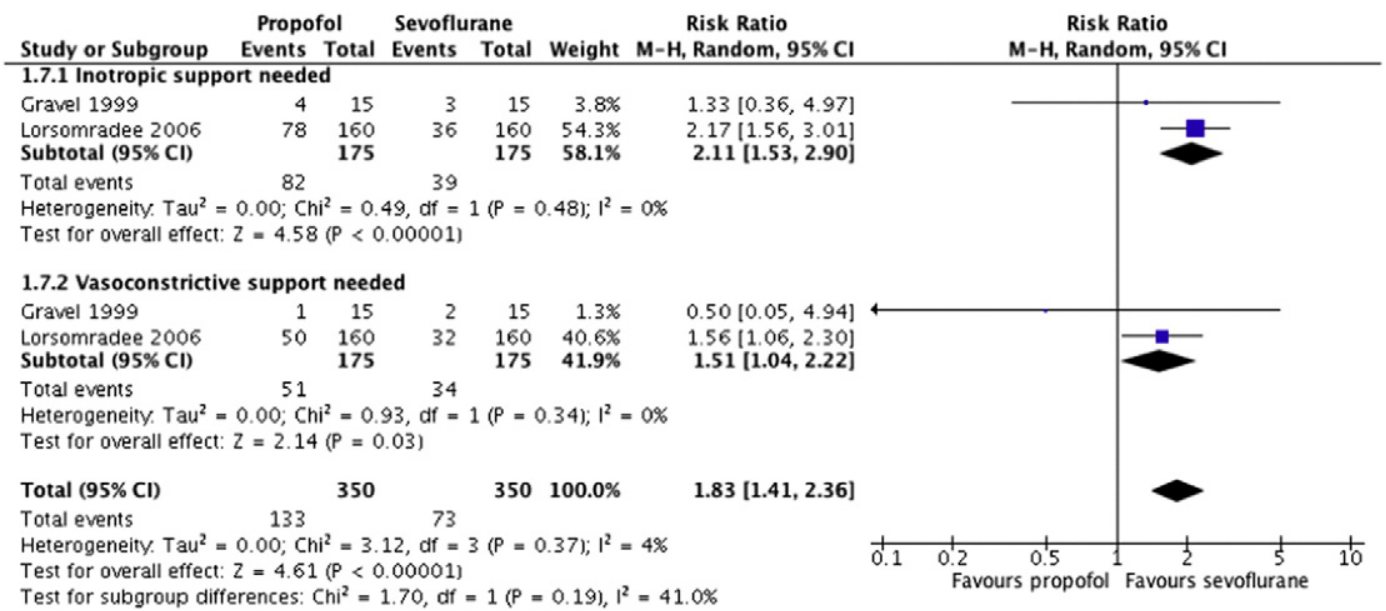

Fig. 5. Meta-analysis of cardiac depression measured by vasoactive drugs after coronary artery bypass grafting on-pump comparing sevoflurane versus propofol. 


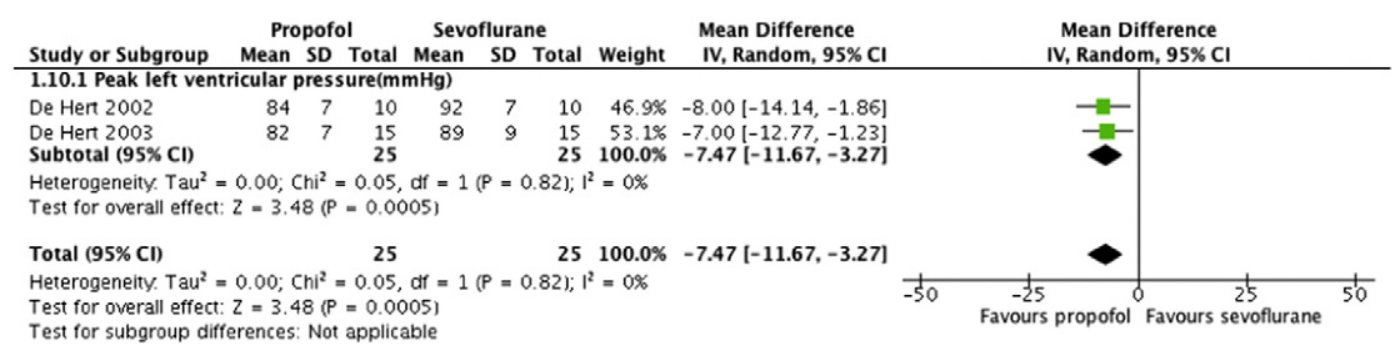

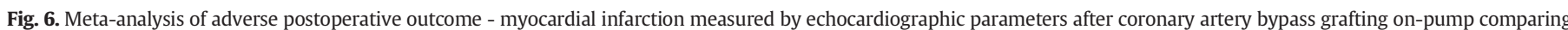
sevoflurane versus propofol.

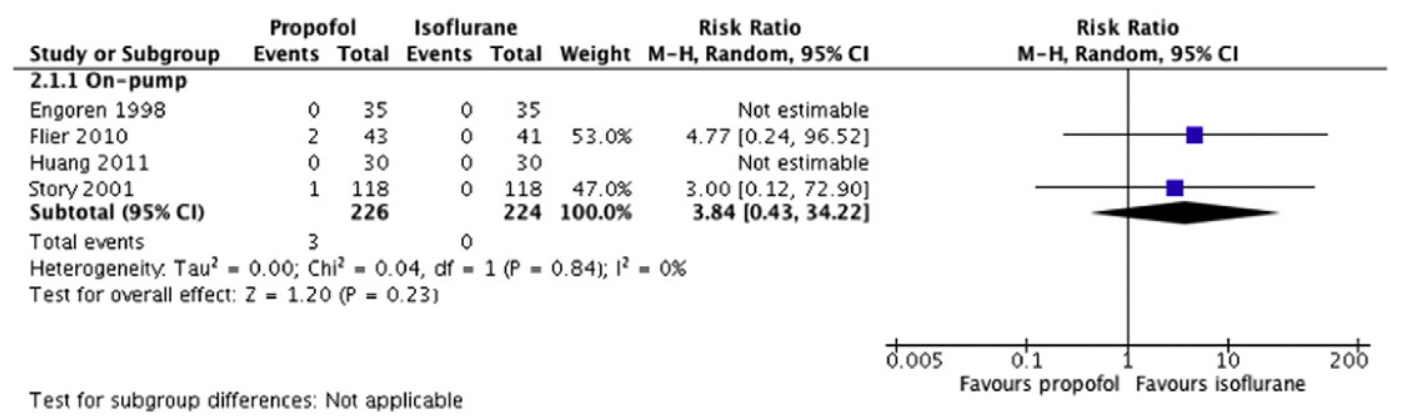

Fig. 7. Meta-analysis of death within 180 to 365 days of surgery comparing isoflurane versus propofol.

measures, particularly as these studies did not report on many of our clinical outcomes, including renal insufficiency and adverse effects.

We were unable to perform two of our 10 planned subgroup analyses: comorbidities (diabetes, hypertension, endocrinopathies, etc.), and age ( $\geq 18$ to 60 years old versus $>60$ years old). We were unable to perform sensitivity analysis by risk of bias or to determine the effect of incomplete outcome data because of insufficient data. Furthermore, we were unable to detect publication bias as there was no meta-analysis with at least 10 included studies.

Even though this review suggests a slightly higher quality of the coronary artery bypass grafting with sevoflurane compared to propofol, results may lack clinical significance because of the small difference. Studies compared propofol with isoflurane (23 studies), sevoflurane (25 studies), desflurane (nine studies), and enflurane (seven studies).

Table 3

GRADE evidence profile for RCTs: Isoflurane versus propofol in an university-affiliated, tertiary care community hospitals in US, Australia and Europe.

\begin{tabular}{|c|c|c|c|c|c|c|}
\hline \multirow[t]{2}{*}{ Outcomes } & \multicolumn{2}{|c|}{$\begin{array}{l}\text { Illustrative comparative } \\
\text { risks* }(95 \% \mathrm{CI})\end{array}$} & \multirow[t]{2}{*}{$\begin{array}{l}\text { Relative effect } \\
(95 \% \mathrm{CI})\end{array}$} & \multirow{2}{*}{$\begin{array}{l}\text { No of } \\
\text { participants } \\
\text { (studies) }\end{array}$} & \multirow{2}{*}{$\begin{array}{l}\text { Quality of the } \\
\text { evidence } \\
\text { (GRADE) }\end{array}$} & \multirow[t]{2}{*}{ Comments } \\
\hline & $\begin{array}{l}\text { Risk with } \\
\text { isoflurane }\end{array}$ & Risk with propofol & & & & \\
\hline Death within $24 \mathrm{~h}$ of surgery & NR & NR & NR & NR & NR & $\begin{array}{l}\text { None included studies reported } \\
\text { on this outcome. }\end{array}$ \\
\hline Death within 30 days of surgery & NR & NR & NR & NR & NR & $\begin{array}{l}\text { None included studies reported } \\
\text { on this outcome. }\end{array}$ \\
\hline $\begin{array}{l}\text { Death within } 180 \text { to } 365 \text { days of surgery } \\
\text { (on-pump) }\end{array}$ & 0 per 1000 & $\begin{array}{l}0 \text { per } 1000 \\
(0 \text { to } 0)\end{array}$ & $\begin{array}{l}3.84 \\
(0.43,34.22)\end{array}$ & $\begin{array}{l}450 \\
\text { (4 studies) }\end{array}$ & $\begin{array}{l}\oplus \oplus \oplus \Theta \\
\text { moderate }^{\mathrm{a}-\mathrm{c}}\end{array}$ & $\begin{array}{l}\text { Baseline risk estimates come } \\
\text { from control arm of the Flier } \\
2010 \text { study. }\end{array}$ \\
\hline $\begin{array}{l}\text { Renal insufficiency (haemofiltration for those } \\
\text { with creatinine increases }>44 \mu \mathrm{m} \text { ) }\end{array}$ & NR & NR & NR & NR & NR & $\begin{array}{l}\text { None included studies } \\
\text { reported on this outcome. }\end{array}$ \\
\hline $\begin{array}{l}\text { Length of stay in the intensive care unit } \\
\text { (on-pump) } \\
\text { follow-up: } 24 \text { h after cardiopulmonary bypass }\end{array}$ & & & $\begin{array}{l}\mathrm{MD}-0.96 \\
(-3.70,1.78)\end{array}$ & 110 (2 studies) & $\begin{array}{l}\oplus \oplus \oplus \Theta \\
\text { moderate }\end{array}$ & \\
\hline $\begin{array}{l}\text { Adverse postoperative outcome - myocardial } \\
\text { infarction (off- and on-pump) } \\
\text { follow-up: until discharge }\end{array}$ & $\begin{array}{l}\text { off-pump: } \\
200 \text { per } 1000 \\
\text { on-pump: } 97 \\
\text { per } 1000\end{array}$ & $\begin{array}{l}\text { off-pump: } 160 \text { fewer } \\
\text { ( } 198 \text { fewer to } 540 \text { more) } \\
\text { on-pump: } 51 \text { fewer ( } 88 \\
\text { fewer to } 141 \text { more) }\end{array}$ & $\begin{array}{l}\text { off-pump: } 0.20 \\
(0.01,3.70) \\
\text { on-pump: } 0.48 \\
(0.09,2.46)\end{array}$ & $\begin{array}{l}\text { off-pump: } 20 \\
\text { ( } 1 \text { study) } \\
\text { on-pump: } 84 \\
\text { ( } 1 \text { study) }\end{array}$ & $\begin{array}{l}\oplus \oplus \oplus \ominus \\
\text { moderate }\end{array}$ & $\begin{array}{l}\text { Baseline risk estimates come } \\
\text { from control arm of the } \\
\text { Kendall } 2004 \text { for off-pump } \\
\text { and Flier } 2010 \text { for on-pump } \\
\text { studies. }\end{array}$ \\
\hline
\end{tabular}

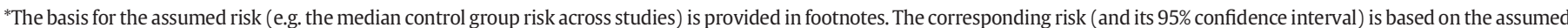
risk in the comparison group and the relative effect of the intervention (and its 95\% CI). CI: Confidence interval; RR: Risk Ratio; NR: Not reported.

GRADE Working Group grades of evidence.

High quality: Further research is very unlikely to change our confidence in the estimate of effect.

Moderate quality: Further research is likely to have an important impact on our confidence in the estimate of effect and may change the estimate.

Low quality: Further research is very likely to have an important impact on our confidence in the estimate of effect and is likely to change the estimate.

Very low quality: We are very uncertain about the estimate.

a There was no serious limitation related to risk of bias, inconsistency $\left(\mathrm{I}^{2}=0 \%\right)$, and indirectness.

b There was serious limitation related to imprecision as $95 \% \mathrm{CI}$ for absolute effects include clinically important benefit and no benefit.

c Publication bias was undetectable.

d There was no serious limitation related to risk of bias, inconsistency $\left(\mathrm{I}^{2}=22 \%\right)$, and indirectness.

e There was no serious limitation related to risk of bias, inconsistency $\left(\mathrm{I}^{2}=\right.$ not applicable), and indirectness. 


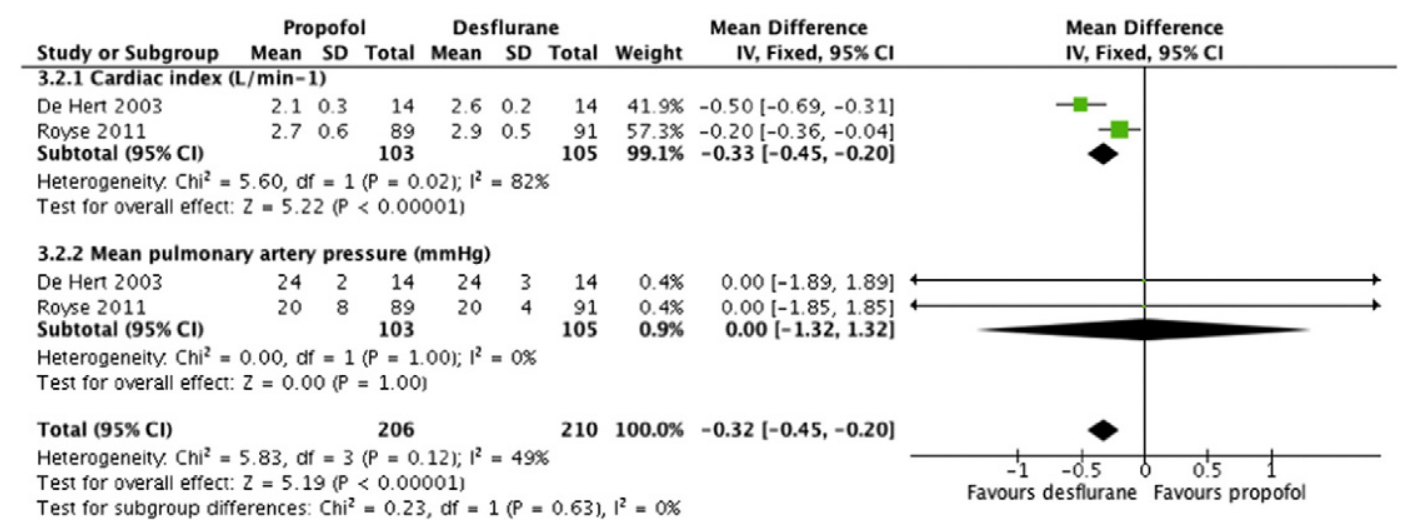

Fig. 8. Meta-analysis of cardiac depression measured by haemodynamic variables after coronary artery bypass grafting on-pump comparing desflurane versus propofol.

However, the majority of them failed to adequately report their results to allow a meta-analysis.

\subsection{Quality of the evidence}

We selected randomized studies for our review, and many of these studies did not report details of randomization, allocation concealment, blinding, and dropouts. The methodological quality was difficult to assess as it was poorly reported in 35 included studies (three or more domains rated as unclear risk of bias) (Fig. 2). The availability of outcome data was limited and trials involving inhalation and intravenous anaesthesia were small regarding sample size, excepted by five studies ( $>300$ patients). Thus the results must be interpreted with caution. Methodological aspects of ten studies had a high risk of introducing bias: inadequate blinding of outcome assessment [30,35-37,53,63,70]; inadequate blinding of participants and personnel $[30,35-37,70,71]$; and poor allocation concealment $[66,79]$. The included studies did not have homogeneous interventions and outcomes, which consequently affects the meta-analysis.
Overall the methodological quality of the included studies was about evenly split between those in which the classification was unclear and those in which the studies were categorised as low risk of bias. The main limiting factors that accounted for a decrease in quality among outcomes were risk of bias and imprecision of results. Although there was only two included studies in the meta-analysis for death within 180 to 365 days of surgery comparing sevoflurane and propofol, we did not downgrade the quality of evidence, as there was no serious limitation related to risk of bias in these studies, inconsistency, imprecision, and indirectness. Subgroup analyses did not provide a convincing explanation for observed variation between the results of the studies. Although we judged studies to be at varying risks of bias overall, the evidence for our main outcomes is drawn from studies at uncertain risk of bias.

\subsection{Potential biases in the review process}

In an attempt to minimize bias, we followed the guidelines provided in the Cochran e Handbook for Systematic Reviews of Interventions. However, our findings and interpretations are limited by the quality

Table 4

GRADE evidence profile for RCTs: Desflurane versus propofol in critical care in Australia, and university hospitals in Italy.

\begin{tabular}{|c|c|c|c|c|c|c|}
\hline \multirow[t]{2}{*}{ Outcomes } & \multicolumn{2}{|c|}{$\begin{array}{l}\text { Illustrative comparative } \\
\text { risks* }(95 \% \mathrm{CI})\end{array}$} & \multirow[t]{2}{*}{$\begin{array}{l}\text { Relative effect } \\
(95 \% \mathrm{CI})\end{array}$} & \multirow{2}{*}{$\begin{array}{l}\text { No of } \\
\text { participants } \\
\text { (studies) }\end{array}$} & \multirow{2}{*}{$\begin{array}{l}\text { Quality of the } \\
\text { evidence } \\
\text { (GRADE) }\end{array}$} & \multirow[t]{2}{*}{ Comments } \\
\hline & $\begin{array}{l}\text { Risk with } \\
\text { desflurane }\end{array}$ & Risk with propofol & & & & \\
\hline Death within $24 \mathrm{~h}$ of surgery & NR & NR & NR & NR & NR & $\begin{array}{l}\text { None included studies reported } \\
\text { on this outcome. }\end{array}$ \\
\hline Death within 30 days of surgery & NR & NR & NR & NR & NR & $\begin{array}{l}\text { None included studies reported } \\
\text { on this outcome. }\end{array}$ \\
\hline $\begin{array}{l}\text { Death within } 180 \text { to } 365 \text { days of surgery } \\
\text { (on-pump) }\end{array}$ & 65 per 1000 & $\begin{array}{l}52 \text { more per } 1000 \\
\text { ( } 9 \text { fewer to } 180 \text { more) }\end{array}$ & $1.81(0.86,3.77)$ & 612 (3 studies) & $\begin{array}{l}\oplus \oplus \oplus \Theta \\
\text { moderate }^{\mathrm{a}-\mathrm{c}}\end{array}$ & $\begin{array}{l}\text { Baseline risk estimates come } \\
\text { from control arm of the De Hert } \\
2009 \text { study. }\end{array}$ \\
\hline $\begin{array}{l}\text { Renal insufficiency (haemofiltration for those } \\
\text { with creatinine increases }>44 \mathrm{um} \text { ) }\end{array}$ & NR & NR & NR & NR & NR & $\begin{array}{l}\text { None included studies reported } \\
\text { on this outcome. }\end{array}$ \\
\hline Length of stay in the intensive care unit & NR & NR & NR & NR & NR & $\begin{array}{l}\text { None included studies reported } \\
\text { on this outcome. }\end{array}$ \\
\hline $\begin{array}{l}\text { Adverse postoperative outcome - myocardial } \\
\text { infarction (on-pump) } \\
\text { follow-up: perioperative }\end{array}$ & 22 per 1000 & $\begin{array}{l}33 \text { more } \\
\text { ( } 7 \text { fewer to } 182 \text { more) }\end{array}$ & $2.52(0.68,9.30)$ & 282 (1 study) & $\begin{array}{l}\oplus \oplus \oplus \Theta \\
\text { moderate }^{\mathrm{b}-\mathrm{d}}\end{array}$ & $\begin{array}{l}\text { Baseline risk estimates come } \\
\text { from control arm of the De Hert } \\
2009 \text { study. }\end{array}$ \\
\hline
\end{tabular}

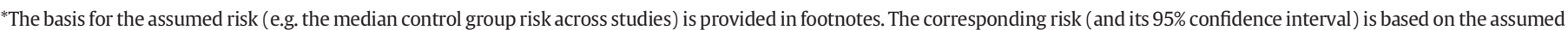
risk in the comparison group and the relative effect of the intervention (and its 95\% CI). CI: Confidence interval; RR: Risk Ratio; NR: Not reported. GRADE Working Group grades of evidence.

High quality: Further research is very unlikely to change our confidence in the estimate of effect.

Moderate quality: Further research is likely to have an important impact on our confidence in the estimate of effect and may change the estimate.

Low quality: Further research is very likely to have an important impact on our confidence in the estimate of effect and is likely to change the estimate.

Very low quality: We are very uncertain about the estimate.

a There was no serious limitation related to risk of bias, inconsistency $\left(\mathrm{I}^{2}=0 \%\right)$, and indirectness.

b There was serious limitation related to imprecision as $95 \% \mathrm{CI}$ for absolute effects include clinically important benefit and no benefit

c Publication bias was undetectable.

d There was no serious limitation related to risk of bias, inconsistency $\left(\mathrm{I}^{2}=\right.$ not applicable), and indirectness. 
and quantity of the available evidence on the effects of inhalation versus intravenous anaesthesia on death within $24 \mathrm{~h}$ of surgery, intraoperative awareness, length of hospital stay and, some adverse postoperative outcomes such as pneumonia, stroke, acute renal failure and, nausea and vomiting and pain. We assessed the risk of bias of the included trials by using the published data, which ultimately may not reflect the truth, and can lead to publication bias. Also, although we did not restrict our search to English language, publication bias due to language may have occurred as we are still awaiting translation from three non-English potential papers [81-83]. However, publication bias could not be answered, as there was insufficient number of studies to allow this inspection through a funnel plot. Furthermore, we did survey study authors to obtain additional information but only a few responded and provided further information. This would reflect on any conclusions drawn from this review.

We were also aware that we pooled very heterogeneous trials in terms of treatment regimens and subgroup analysis by type of outcomes. However, all the included studies have similar surgical profile patients.

\subsection{Implications for practice}

In conducting this review we have attempted to answer the following clinical questions:

- Is sevoflurane better than propofol?

High-quality evidence suggests that sevoflurane is more effective than propofol in decreasing the rates of death within 180 to 365 days of surgery for patients undergoing on-pump coronary artery bypass grafting. Also, some evidence suggests that sevoflurane is more efficacious than propofol on both inotropic and vasoconstrictor support needed; and that the cardiac index is minimally influenced by administration of sevoflurane compared to propofol. Low-quality evidence indicates no difference in the efficacy between sevoflurane and propofol in decreasing both the rates of death within 30 days of surgery and renal insufficiency for patients undergoing on-pump and off-pump coronary artery bypass grafting.

- Is isoflurane better than propofol?

Moderate-quality evidence indicates no difference in the efficacy between propofol and isoflurane in decreasing the rates of death within 180 to 365 days of surgery for patients undergoing on-pump coronary artery bypass grafting.

- Is desflurane better than propofol?

Moderate-quality evidence indicates no difference in the efficacy between propofol and desflurane in decreasing the rates of death within 180 to 365 days of surgery for patients undergoing on-pump coronary artery bypass grafting. However, some evidence suggests that the cardiac index is minimally influenced by administration of desflurane compared to propofol.

- Is enflurane better than propofol?

Moderate-quality evidence indicates no difference in the efficacy between propofol and enflurane in decreasing the rates of death within 30 days of surgery for patients undergoing on-pump coronary artery bypass grafting.

\subsection{Implications for research}

This review highlights the urgent need to conduct well-designed trials in this field. It is important that future trials should be adequately powered and should measure the following:
- Standardized outcome measures such as death; renal insufficiency; cardiac depression; and intraoperative awareness;

- Head-to-head comparisons of different types of inhaled anaesthetics;

- Cost-effectiveness of inhaled compared to intravenous anaesthetics;

- Adverse effects data such as pneumonia, brain injury and heart failure.

\section{Authors' contributions}

RED: conception, study design, interpretation of data, analysis, drafting article, revision, and final approval. JEGP: conception, study design, revision, and final approval. AA: analysis, data acquisition, drafting article, revision, and final approval. HG: data acquisition, analysis, and final approval. APA: search strategies, and final approval. AGB: analysis, data acquisition, drafting article, revision, and final approval. LGB: data acquisition, revision, and final approval. LDO: drafting article, revision, and final approval. LCL: analysis, data acquisition, drafting article, revision, and final approval. PM: conception, study design, interpretation of data, analysis, drafting article, revision, and final approval.

Supplementary data to this article can be found online at http://dx. doi.org/10.1016/j.jclinane.2017.05.010.

\section{Financial support and sponsorship}

The authors have declared that no competing interests exist. Regina El Dib received a Brazilian Research Council (CNPq) scholarship (\#310953/2015-4).

\section{Conflicts of interest}

The authors report no conflicts of interest. The funding agency played no role in the conduct of the research or preparation of the manuscript.

\section{Acknowledgments}

We would like to thank Jane Cracknell (co-ordinator of the Cochrane Anaesthesia, Critical, and Emergency Care); Mark Neuman (content editor of the Cochrane Anaesthesia, Critical, and Emergency Care); Nathan Pace (statistical editor of the Cochrane Anaesthesia, Critical, and Emergency (are) for their help and editorial advice during the preparation of this review. We also would like to thank Norma Sueli Pinheiro Módolo for conceiving the idea of this review. Furthermore, we would like to thank Joseph L Mathew, Luis Felipe Orsi Gameiro, Mariel Orsi Gameiro, Marília P Módolo, and Marcos A Marton for their help during the preparation of the protocol.

\section{References}

[1] Eaton MP, Bailey PL. Cardiovascular pharmacology of anesthetics. Cardiac anesthesia - principles and clinical practice. Philadelphia: Lippincott Williams \& Wilkins; 2001 p. 295-315.

[2] Pagel PS. Cardioprotection by volatile anesthetics established scientific principle or lingering clinical uncertainty? J Cardiothorac Vasc Anesth 2009;23:589-93 [PubMed: 19789055].

[3] Pagel P, Farber NE, Patt Jr PF, Warttier DC. Cardiovascular pharmacology. In: Miller RD, Eriksson LI, Fleisher LA, Wiener-Kronish JP, Young WL, editors. Miller's anesthesia. Philadelphia: Churchil Livingstone Elsevier; 2010.

[4] Landoni G, Biondi-Zoccai GG, Zangrillo A, Bignami E, D'Avolio S, Marchetti C, et al Desflurane and sevoflurane in cardiac surgery: a meta-analysis of randomized clinical trials. J Cardiothorac Vasc Anesth 2007;21(4):502-11 [PubMed: 17678775].

[5] Yu CH, Beattie WS. The effects of volatile anesthetics on cardiac ischemic complications and mortality in CABG: a meta-analysis. Can J Anaesth 2006;53(9):906-18 [PubMed: 16960269].

[6] Symons JA, Myles PS. Myocardial protection with volatile anaesthetic agents during coronary artery bypass surgery: a meta-analysis. Br J Anaesth 2006;97(2):127-36 [PubMed: 16793778]

[7] Bland JHL, Lowenstein E. Halothane-induced decrease experimental myocardial ischemia in the non-failing canine heart. Anesthesiology 1976;45:287-93 [PubMed: 962178]. 
[8] Freedman BM, Hamm DP, Everson CT, Wechsler Christian CM. Enflurane enhances postischemic function recovery in isolated rat heart. Anesthesiology 1985;62: 29-33 [PubMed: 3966666].

[9] De Hert SG, Van der Linden PJ, Cromheecke S, Meeus R, Nelis A, Van Reeth V, et al. Cardioprotective properties of sevoflurane in patients undergoing coronary surgery with cardiopulmonary bypass are related to the modalities of its administration. Anesthesiology 2004;101:299-310 [PubMed: 15277911].

[10] De Hert SG, Turani F, Mathur S, Stowe DF. Cardioprotection with volatile anesthetics: mechanisms and clinical implications. Anesth Analg 2005;100(6):1584-93 [PubMed: 15920178]

[11] Lorsomradee S, Cromheecke S, Lorsomradee S, De Hert SG. Cardioprotection with volatile anesthetics in cardiac surgery. Asian Cardiovasc Thorac Ann 2008:16(3): 256-64.

[12] Higgins JPT, Green S. Cochrane handbook for systematic reviews of interventions 5.1.0. The Cochrane Collaboration: United Kingdom and Australia; 2011.

[13] Moher D, Liberati A, Tetzlaff J, Altman DG. The PRISMA Group Preferred reporting items for systematic reviews and meta-analyses: the PRISMA statement. PLoS Med 2009;6 (e1000097)

[14] Bellomo R, Ronco C, Kellum JA, Mehta RL. Palevsky P; acute dialysis quality initiative workgroup. Acute renal failure - definition, outcome measures, animal models, fluid therapy and information technology needs: the second international consensus conference of the acute dialysis quality initiative (ADQI) group. Crit Care 2004;8(4): R204-12.

[15] Mehta RL, Kellum JA, Shah SV, Molitoris BA, Ronco C, Warnock DG, et al. Acute kidney injury network: report of an initiative to improve outcomes in acute kidney injury. Crit Care 2007;11(2):R31.

[16] Higgins JP, Altman DG, Gøtzsche PC, Jüni P, Moher D, Oxman AD, et al. The Cochrane Collaboration's tool for assessing risk of bias in randomised trials. BMJ 2011;343: d5928.

[17] Guyatt GH, Busse JW. Modification of Cochrane tool to assess risk of bias in randomized trials. DistillerSR. Available: http://distillercer.com/resources/; 2016.

[18] Guyatt GH, Oxman AD, Vist G, Kunz R, Brozek J, Alonso-Coello P, et al. GRADE guidelines: 4. Rating the quality of evidence-study limitations (risk of bias). J Clin Epidemiol 2011;64:407-15

[19] Guyatt GH, Oxman AD, Kunz R, Brozek J, Alonso-Coello P, Rind D, et al. GRADE guidelines 6. Rating the quality of evidence-imprecision. J Clin Epidemiol 2011;64: 1283-93.

[20] Guyatt GH, Oxman AD, Kunz R, Woodcock J, Brozek J, Helfand M, et al. GRADE guidelines: 7. Rating the quality of evidence-inconsistency. J Clin Epidemiol 2011;64: 1294-302.

[21] Guyatt GH, Oxman AD, Kunz R, Woodcock J, Brozek J, Helfand M, et al. GRADE guidelines: 8. Rating the quality of evidence-indirectness. J Clin Epidemiol 2011;64 1303-10.

[22] Guyatt GH, Oxman AD, Montori V, Vist G, Kunz R, Brozek J, et al. GRADE guidelines: 5. Rating the quality of evidence-publication bias. J Clin Epidemiol 2011;64: 1277-82.

[23] Nordic Cochrane Centre, Cochrane Collaboration. Review Manager (RevMan) version 5.3. Copenhagen: the nordic cochrane centre, the Cochrane collaboration; 2011

[24] Conzen PF, Fischer S, Detter C, Peter K. Sevoflurane provides greater protection of the myocardium than propofol in patients undergoing off-pump coronary artery bypass surgery. Anesthesiology 2003;99(4):826-33 [PubMed: 14508313].

[25] Guarracino F, Landoni G, Tritapepe L, Pompei F, Leoni A, Aletti G, et al. Myocardia damage prevented by volatile anesthetics: a multicenter randomized controlled study. J Cardiothorac Vasc Anesth 2006;20(4):477-83 [PubMed: 16884976].

[26] Tritapepe L, Landoni G, Guarracino F, Pompei F, Crivellari M, Maselli D, et al. Cardiac protection by volatile anaesthetics: a multicentre randomized controlled study in patients undergoing coronary artery bypass grafting with cardiopulmonary bypass. Eur J Anaesthesiol 2007;24(4):323-31 [PubMed: 17156509].

[27] Baki ED, Aldemir M, Kokulu S, Koca HB, Ela Y, Gul Sivaci R, et al. Comparison of the effects of desflurane and propofol anesthesia on the inflammatory response and S100ß protein during coronary artery bypass grafting. Inflammation 2013;36(6): 1327-33 [PubMed: 23775574]

[28] Ballester M, Llorens J, Garcia-de-la-Asuncion J, Perez-Griera Tebar E, Martinez-Leon J, et al. Myocardial oxidative stress protection by sevoflurane vs. propofol: a randomized controlled study in patients undergoing off-pump coronary artery bypass graft surgery. Eur J Anaesthesiol 2011;28(12):874-81 [PubMed: 21946824].

[29] Bein B, Renner J, Caliebe D, Scholz J, Paris A, Fraund S, et al. Sevoflurane but not propofol preserves myocardial function during minimally invasive direct coronary artery bypass surgery. Anesth Analg 2005;100(3):610-6 [PubMed: 15728039].

[30] Botero CA, Smith CE, Holbrook C, Chavez AM, Snow NJ, Hagen JF, et al. Total intravenous anesthesia with a propofol-ketamine combination during coronary artery surgery. J Cardiothorac Vasc Anesth 2000;14:409-15 [PubMed: 10972606]

[31] Chang FL, Lin SL, Tsai CS, Yeh CC, Wu CT, Wong CS. Closed-circuit isoflurane-based anesthesia provides better fast-tracking anesthesia than fentanyl/propofol-based anesthesia for off-pump coronary artery bypass graft surgery. Acta Anaesthesiol Taiwan 2007;45(3):135-9 [PubMed: 17972615].

[32] De Hert SG, ten Broecke PW, Mertens E, Van Sommeren EW, De Blier IG, Stockman BA, et al. Sevoflurane but not propofol preserves myocardial function in coronary surgery patients. Anesthesiology 2002;97(1):42-9 [PubMed: 12131102].

[33] De Hert SG, Cromheecke S, ten Broecke PW, Mertens E, De Blier IG, Stockman BA et al. Effects of propofol, desflurane, and sevoflurane on recovery of myocardial function after coronary surgery in elderly high-risk patients. Anesthesiology 2003;99(2): 314-23 [PubMed: 12883404].

[34] De Hert S, Vlasselaers D, Barbé R, Ory JP, Dekegel D, Donnadonni R, et al. A comparison of volatile and non volatile agents for cardioprotection during on-pump coronary surgery. Anaesthesia 2009;64(9):953-60 [PubMed: 19686479].
[35] Demirci A, Unver S, Karadeniz U, Cetintas Y, Kazanci D, Erdemli O. Middle cerebral arterial blood flow velocity and hemodynamics in heart surgery. Asian Cardiovasc Thorac Ann 2007;15(2):97-101 [PubMed: 17387189].

[36] Driessen JJ, Giart M. Comparison of isoflurane and midazolam as hypnotic supplementation to moderately high-dose fentanyl during coronary artery bypass grafting: effects on systemic hemodynamics and early postoperative recovery profile. J Cardiothorac Vasc Anesth 1997;11:740-5 [PubMed: 9327316].

[37] El Azab SR, Rosseel PM, De Lange JJ, van Wijk EM, van Strik R, Scheffer GJ. Effect of VIMA with sevoflurane versus TIVA with propofol or midazolam-sufentanil on the cytokine response during CABG surgery. Eur J Anaesthesiol 2002;19(4):276-82 [PubMed: 12074417].

[38] Engoren MC, Kraras C, Garzia F. Propofol-based versus fentanyl-isoflurane-based anesthesia for cardiac surgery. J Cardiothorac Vasc Anesth 1998;12(2):177-81 [PubMed: 9583550].

[39] Flier S, Post J, Concepcion AN, Kappen TH, Kalkman CJ, Buhre WF. Influence of propofol-opioid vs isoflurane-opioid anaesthesia on postoperative troponin release in patients undergoing coronary artery bypass grafting. Br J Anaesth 2010;105(2): 122-30 [PubMed: 20573633].

[40] Gravel NR, Searle NR, Taillefer J, Carrier M, Roy M, Gagnon L. Comparison of the hemodynamic effects of sevoflurane anesthesia induction and maintenance vs TIVA in CABG surgery. Can J Anaesth 1999;46(3):240-6 [PubMed: 10210048].

[41] Haessler R, Schwender D, Leppmeier U, Klasing S, Rindfleisch F, Peter K. Anaesthesia for coronary artery bypass grafting: opioid-analgesia combined with either flunitrazepam, propofol or isoflurane. Acta Anaesthesiol Scand 1993;37(6):532-40 [PubMed: 8213015].

[42] Hall RI, Murphy JT, Moffitt EA, Landymore R, Pollak PT, Poole L. A comparison of the myocardial metabolic and haemodynamic changes produced by propofol-sufentanil and enflurane-sufentanil anaesthesia for patients having coronary artery bypass graft surgery. Can J Anaesth 1991;38(8):996-1004 [PubMed: 1836422].

[43] Helman JD, Leung JM, Bellows WH, Pineda N, Roach GW, Reeves JD, et al. The risk of myocardial ischemia in patients receiving desflurane versus sufentanil anesthesia for coronary artery bypass graft surgery. Anesthesiology 1992;77:47-62 [PubMed: 1535185].

[44] Huang Z, Zhong X, Irwin MG, Ji S, Wong GT, Liu Y. Synergy of isoflurane preconditioning and propofol postconditioning reduces myocardial reperfusion injury in patients. Clin Sci 2011;121(2):57-69 [PubMed: 21291422].

[45] Huseidzinović I, Barisin S, Bradić N, Milanović R. Early cardioprotective effect of sevoflurane on left ventricular performance during coronary artery bypass grafting on a beating heart: randomized controlled study. Croat Med J 2007;48(3):333-40 [PubMed: 17589976].

[46] Jerath A, Beattie SW, Chandy T, Karski J, Djaiani G, Rao V, et al. Volatile-based shortterm sedation in cardiac surgical patients: a prospective randomized controlled trial. Crit Care Med 2015;43(5):1062-9 [PubMed: 25756412].

[47] Jia L, Dong R, Zhang F, Wang W, Lu H, Luo Y, et al. Propofol provides more effective protection for circulating lymphocytes than sevoflurane in patients undergoing offpump coronary artery bypass graft surgery. J Cardiothorac Vasc Anesth 2015;29: 1172-9 [PubMed: 26205644].

[48] Kanbak M, Saricaoglu F, Avci A, Ocal T, Koray Z, Aypar U. Propofol offers no advantage over isoflurane anesthesia for cerebral protection during cardiopulmonarybypass: a preliminary study of S-100ß protein levels. Can J Anesth 2004;51(7):712-7 [PubMed: 15310641].

[49] Kawamura T, Kadosaki M, Nara N, Kaise A, Suziki H, Endo S, et al. Effects of sevoflurane on cytokine balance in patients undergoing coronary artery bypass graft surgery. J Cardiotharacic Vasc Anesth 2006;20(4):503-8 [PubMed: 16884979].

[50] Kendall JB, Russell GN, Scawn ND, Akrofi M, Cowan CM, Fox MA. A prospective, randomised, single-blind pilot study to determine the effect of anaesthetic technique on troponin $T$ release after off-pump coronary artery surgery. Anaesthesia 2004;59(6):545-9 [PubMed: 15144293].

[51] Kim TY, Kim DK, Yoon TG, Lim JA, Woo NS, Chee HK, et al. Myocardial injury in remifentanil-based anaesthesia for off-pump coronary artery bypass surgery: an equipotent dose of sevoflurane versus propofol. Anaesth Intensive Care 2011; 39(3):418-25 [PubMed: 21675061]

[52] Kirov MY, Lenkin AI, Kuzkov VV, Suborov EV, Slastilin VY, Borodin VV, et al. Single transpulmonary thermodilution in off-pump coronary artery bypass grafting: haemodynamic changes and effects of different anaesthetic techniques. Acta Anaesthesiol Scand 2007;51(4):426-33 [PubMed: 17378780]

[53] Kottenberg E, Thielmann M, Bergmann L, Heine T, Jakob H, Heusch G, et al. Protection by remote ischemic preconditioning during coronary artery bypass graft surgery with isoflurane but not propofol - a clinical trial. Acta Anaesthesiol Scand 2012:56:30-8 [PubMed: 22103808].

[54] Landoni G, Guarracino F, Cariello C, Franco A, Baldassarri R, Borghi G, et al. Volatile compared with total intravenous anaesthesiain patients undergoing high-risk cardiac surgery: a randomized multicentre study. Br J Anaesth 2014;113(6):955-63 [PubMed: 25186820].

[55] Law-Koune JD, Raynaud C, Liu N, Dubois C, Romano M, Fischler M. Sevofluraneremifentanil versus propofol-remisfentanil anesthesia at a similar bispectral level for off-pump coronary artery surgery: no evidence of reduced myocardial ischemia. J Cardiothorac Vasc Anesth 2006;20(4):484-92 [PubMed: 16884977].

[56] Likhvantsev VV, Landoni G, Levikov DI, Grebenchikov OA, Skripkin YV, Cherpakov RA. Sevoflurane versus total intravenous anesthesia for isolated coronary artery bypass surgery with cardiopulmonary bypass: a randomized trial. J Cardiothorac Vasc Anesth 2016;30(5):1221-7 [PubMed: 27431595].

[57] Lorsomradee S, Cromheecke S, Lorsomradee S, De Hert SG. Effects of sevoflurane on biomechanical markers of hepatic and renal dysfunction after coronary artery surgery. J Cardiothorac Vasc Anesth 2006;20(5):684-90 [PubMed: 17023289]. 
[58] Lu CC, Ho ST, Wang JJ, Wong CS, Tsai CS, Chang SY. Minimal low-flow isofluranebased anesthesia benefits patients undergoing coronary revascularization via preventing hyperglycemia and maintaining metabolic homeostasis. Acta Anaesthesiol Sin 2003;41(4):165-72 [PubMed: 14768513].

[59] Lucchinetti E, Hofer C, Bestmann L, Hersberger M, Feng J, Zhu M. Gene regulatory control of myocardial energy metabolism predicts postoperative cardiac function in patients undergoing off-pump coronary artery bypass graft surgery: inhalational versus intravenous anesthetics. Anesthesiology 2007;106(3):444-57 [PubMed: 17325502].

[60] Mora CT, Dudek C, Torjman MC, White PF. The effects of anesthetic technique on the hemodynamic response and recovery profile in coronary revascularization patients. Anesth Analg 1995;81(5):900-10 [PubMed: 7486076].

[61] Mroziński P, Lango R, Biedrzycka A, Kowalik MM, Pawlaczyk R, Rogowski J. Comparison of haemodynamics and myocardial injury markers under desflurane vs. propofol anaesthesia for off-pump coronary surgery. A prospective randomised trial. Anaesthesiol Intensiv Ther 2014;46(1):4-13 [PubMed: 24643920].

[62] Murphy T, Landymore RW, Hall RI. Midazolam-sufentanil vs sufentanil-enflurane for induction of anaesthesia for CABG surgery. Can J Anaesth 1998;45(12):1207-10 [PubMed: 10051942].

[63] Myles PS, Buckland MR, Weeks AM, Bujor MA, McRae R, Langley M, et al. Hemodynamic effects, myocardial ischemia, and timing of tracheal extubation with propofolbased anesthesia for cardiac surgery. Anesth Analg 1997;84(1):12-9 [PubMed: 8988992].

[64] Nandate K, Vuysteke A, Ratsep I, Messahel S, Oduro-Dominah, Menon DK, et al. Effects of isoflurane, sevoflurane and propofol anaesthesia on jugular venous oxygen saturation in patients undergoing coronary artery bypass surgery. $\mathrm{Br} \mathrm{J}$ Anaesth 2000;84(5):631-3.

[65] Ohqvist G, Settergren G, Ekeström S, Brodin LA. The influence of isoflurane on blood flow in coronary bypass grafts. Acta Anaesthesiol Scand 1985;29(8):758-63 [PubMed: 3878652].

[66] Orriach JLG, Ortega MG, Aliaga MR, Iglesias P, Navarro MR, Mañas JC. Prolonged sevoflurane administration in the off-pump coronary artery bypass graft surgery: beneficial effects. J Crit Care 2013;28(5):e13-8 [PubMed: 23886454].

[67] Parker FC, Story DA, Poustie SP, Liu G, McNicol L. Time to tracheal extubation after coronary artery surgery with isoflurane, sevoflurane, or target-controlled propofol anesthesia: a prospective, randomized, controlled trial. J Cardiothorac Vasc Anesth 2004;18(5):613-9 [PubMed: 15578473].

[68] Parsons RS, Jones RM, Wrigley SR, MacLeod KG, Platt MW. Comparison of desflurane and fentanyl-based anaesthetic techniques for coronary artery bypass surgery. $\mathrm{Br} \mathrm{J}$ Anaesth 1994;72(4):430-8 [PubMed: 8155446].

[69] Phillips AS, McMurray TJ, Mirakhur RK, Gibson FM, Elliott P. Propofol-fentanyl anesthesia: a comparison with isoflurane-fentanyl anesthesia in coronary artery bypass grafting and valve replacement surgery. J Cardiothorac Vasc Anesth 1994;8(3): 289-96 [PubMed: 8061262].

[70] Rieke H, Kazmaier S, Lange H, Weyland A, Sonntag H. Do anaesthetic techniques influence the incidence of postoperative myocardial ischaemia? A study in patients after coronary artery bypass graft surgery. Anaesthesiol Reanim 1999;24(5):120-9 [PubMed: 10596203].
[71] Royse CF, Andrews DT, Newman SN, Stygall J, Williams Z, Pang J, et al. The influence of propofol or desflurane on postoperative cognitive dysfunction in patients undergoing coronary artery bypass surgery. Anaesthesia 2011;66(6):455-64 [PubMed: 21501129].

[72] Schoen J, Husemann L, Tiemeyer C, Lueloh A, Sedemund-Adib B, Berger KU, et al Cognitive function after sevoflurane- vs propofol-based anaesthesia for on-pump cardiac surgery: a randomised controlled trial. Br J Anaesth 2011;106(6):840-50 [PubMed: 21518736].

[73] Singh SP, Kappor PM, Chowdhury U, Kiran U. Comparison of S100ß levels, and their correlation with hemodynamic indices in patients undergoing coronary artery bypass grafting with three different anesthetic techniques. Ann Card Anaesth 2011; 14(3):197-202 [PubMed: 21860192].

[74] Sorbara C, Pittarello D, Rizzoli G, Pasini L, Armellin G, Bonato R, et al. Propofol-fentanyl versus isoflurane-fentanyl anesthesia for coronary artery bypass grafting: effect on myocardial contractility and peripheral hemodynamics. J Cardiothorac Vasc Anesth 1995;9(1):18-23 [PubMed: 7718750].

[75] Story DA, Poustie S, Liu G, McNicol PL. Changes in plasma creatinine concentration after cardiac anesthesia with isoflurane, propofol, or sevoflurane: a randomized clinical trial. Anesthesiology 2001;95(4):842-8 [PubMed: 11605922]

[76] Suryaprakash S, Chakravarthy M, Muniraju G, Pandey S, Mitra S, Shivalingappa B et al. Myocardial protection during off pump coronary artery bypass surgery: a comparison of inhalation anesthesia with sevoflurane or desflurane and total intravenous anesthesia. Ann Card Anaesth 2013;16(1):4-8 [PubMed: 23287079].

[77] Tempe DK, Dutta DD, Garg M, Minhas H, Tomar A, Virmani S. Myocardial protection with isoflurane during off-pump coronary artery bypass grafting: a randomized trial. J Cardiothorac Vasc Anesth 2011;25(1):59-65 [PubMed: 20580572].

[78] Underwood SM, Davies SW, Feneck RO, Walesby RK. Anaesthesia for myocardial revascularization. Anaesthesia 1992;47:939-45 [PubMed: 1466432]

[79] Urzua J, Serra M, Lema G, Canessa R, Gonzalez R, Meneses G. Comparison of isoflurane, halothane and fentanyl in patients with decreased ejection fraction undergoing coronary surgery. Anaesth Intensive Care 1996;24(5):579-84 [PubMed: 8909670].

[80] Xia Z, Zhiyong H, Ansley DM. Large-dose propofol during cardiopulmonary bypass decreases biochemical markers of myocardial injury in coronary surgery patients: a comparasion with isoflurane. Anesth Analg 2006;103(3):527-32 [PubMed: 16931656].

[81] Ishihara H, Matsuki A, Hashimoto H, Koh H, Kudoh T, Ishikawa T. Clinical study on total intravenous anesthesia with droperidol, fentanyl and ketamine-15. Application for cardiac anesthesia. Masui 1992;41(9):1474-81 [PubMed: 1433880].

[82] Pagnin A, Ceriana P, Maurelli M, Locatelli A, Bertollo D, Mazza MP, et al. Comparison between propofol and isoflurane in patients undergoing aorto-coronary bypass. Effect on systemic and coronary circulation [Confronto tra propofol e isoflurano in pazienti sottoposti ad intervento di bypass aorto-coronarico. Effetti sul circolo sistemico e coronarico]. Minerva Anestesiol 1992;58(6):361-7 [PubMed: 1508343].

[83] Procaccini B, Clementi G. Propofol in coronary diseases. Haemodynamic evaluation of some anesthetic regimes. Minerva Anestesiol 1996;62(7-8):249-57 [PubMed: 8999375]. 